\title{
Loose Ties? Determinants of Father-Child Contact after Separation in Germany
}

Katja Köppen: $\quad$ University of Rostock

Institute of Sociology and Demography

Ulmenstr. 69

18055 Rostock

Germany

katja.koeppen@uni-rostock.de

Michaela Kreyenfeld: Hertie School of Governance

Friedrichstraße 180

10117 Berlin

Germany

kreyenfeld@hertie-school.org

Heike Trappe: $\quad$ University of Rostock

Institute of Sociology and Demography

Ulmenstr. 69

18055 Rostock

Germany

heike.trappe@uni-rostock.de

\section{ACKNOWLEDGEMENTS}

The research leading to these results has received funding from the German Science Foundation

(DFG) under the grant agreement number KR 2855/3-1 \& TR 457/7-1. This paper uses data from the German Family Panel pairfam, coordinated by Josef Brüderl, Karsten Hank, Johannes Huinink, Bernhard Nauck, Franz Neyer, and Sabine Walper. Pairfam is funded as a long-term project by the DFG. 


\section{Loose Ties? Determinants of Father-Child Contact after Separation in Germany}

Objective: This paper examines the determinants of father-child contact in Germany after divorce and separation, with a special emphasis on the role of legal child support.

Background: The contact separated fathers have with their children is a policy-relevant issue that has been intensively addressed in previous research for the US, the UK, and Canada. For continental Europe, there has been far less research on this topic. This paper investigated how fathers' union status at childbirth, custody arrangements, and past and present partnership dynamics affect the level of contact they had with their first-born child from a prior union.

Method: Data were used from wave 2 (2009/10) to wave 8 (2015/16) of the German family panel pairfam (www.pairfam.de). With a final sample size of 285 fathers, population average logistic models were estimated that examined non-resident fathers' probability of having frequent contact versus having little or no contact with their first-born children.

Results: Whether a non-resident father shared legal custody with the mother or not was a decisive factor in whether he had regular contact with his minor child, particularly if he was not living with the mother of the child at the time of delivery. There were strong interaction effects between having joint legal custody and the time since the parental separation. Joint legal custody did not have an immediate impact on father-child contact around the time of separation, but as time elapsed, men without joint legal custody were more likely to lose contact with their children than men with joint legal custody.

Conclusion: Joint legal custody may provide an institutional arrangement for separated parents to exercise their responsibility for the well-being of their children and thus be conducive to regular father-child contact.

Keywords: custody, divorce, fatherhood, parent-child relationships, separation 
The images and expectations of fatherhood have undergone radical changes in recent decades. While the normative pressure to act as an 'involved father' has increased over time, fathers themselves have also expressed a growing desire to be more actively involved in the lives of their children (Adler \& Lenz, 2016; Kaufman, 2013). This normative expectation and individual desire might extend beyond parental breakup. Given the high rates of separation and divorce in most developed countries and a situation where children often reside with their mothers afterwards, a father's ability to remain involved in the lives of his children after a union dissolution may, however, be limited.

The contact separated fathers have with their children is a policy-relevant issue that has been intensively addressed in previous research for the US, the UK, and Canada (e.g., Amato et al., 2009; Cheadle et al., 2010; Juby et al., 2007; Stewart, 2010). For continental Europe, there has been far less research on this topic (see, however, Régnier-Loilier, 2015; Skevig, 2006). Kalmijn (2015a: 252) noted in this context that "even the simplest facts such as the percentages of co-parenting arrangements after divorce are unknown for most European countries”. Thus, the question of whether previous findings for English-speaking countries can be translated to different legal contexts and different cultural understandings of fatherhood has remained unanswered.

Our study focuses on Germany, which used to be laggard in the European context in supporting the rights of divorced and separated fathers (Balomatis, 2016). It is only recently that policy reforms were enacted that strengthened the rights of separated and divorced fathers towards their children (Dethloff, 2015). Most significant in this context is a policy reform enacted in 1998 that has granted unmarried fathers the right to joint legal custody. The question of whether joint legal custody facilitates father-child contact among unmarried fathers has, however, been unanswered so far. In this article, we add to the literature on the determinants of father-child contact after parental separation. Access to detailed union and fertility histories allows us to 
place fathers' behavior into a biographical context. In particular, we examine how union status at childbirth, repartnering, and subsequent childbirth shape the involvement of non-resident fathers with their children. Most importantly, our data enable us to investigate how legal custody is associated with father-child contact after separation, and how patterns differ by union status at childbirth and duration since separation.

\section{BACKGROUND}

The extent to which non-resident fathers maintain contact with their children, take on responsibilities to care for them, and remain emotionally involved with them after separation and divorce can be seen as expressions of men's identities as fathers. In relation to those identities, separated fathers choose to spend time, money, and energy on their children (IhingerTallman et al., 1993). Previous research has established that the extent of non-resident fathers' involvement with their children, in particular father-child contact, is being influenced by fathers' past and present partnership dynamics, by fathers' socioeconomic resources, by the quality of the interparental relationship, and by the social policy context (Kalmijn, 2015a; Seltzer, 1991; Stewart, 1999; Cheadle et al., 2010; Haux et al., 2015). Fathers’ union history prior to separation is one of the key predictors for their later involvement. Fathers who have never co-resided with the mother of their children often remain absent from their children's lives altogether (Guzzo, 2009; Kiernan, 2006; Skevik, 2006), possibly because they were unable to develop a strong "paternal identity” (Ihinger-Tallman et al., 1993: 552). Fathers who were married are more likely to remain involved than men who were in cohabiting unions or in “romantic relationships” when their children were born (Tach et al., 2010). Furthermore, fatherchild contact tends to decrease with increasing duration since the separation (Stephen et al., 1994; Stephens, 1996). The effects of duration since separation are, however, closely related to the age of the child, which increases in tandem with time since separation. 
The partnership behavior of the parents after separation is another decisive factor in explaining the frequency of father-child contact. There is consistent evidence that the intensity of the relationship between a non-resident father and his children worsens when either the mother or the father repartners (Bradshaw et al., 1999; Stephens, 1996; Stewart, 2010). A new partnership can impose time constraints and additional responsibilities that may interfere with established patterns of father-child contact (Stephens, 1996). The father's new partner may also pressure him to invest more in her own children, possibly at the cost of his ability to invest in his children from a previous relationship (Kalmijn, 2015b). The arrival of a new child is another factor that can negatively affect the relationship of the non-resident father and his children (Juby et al., 2007; Manning \& Smock, 1999). It is argued that fathers tend to shift their investments to the children with whom they share a residence at the expense of those with whom they no longer live (Furstenberg \& Cherlin, 1991; Tach et al., 2014; Townsend, 2002).

With respect to fathers' socioeconomic background, existing research largely affirms a “socioeconomic-advantaged parenting perspective” (Stephens, 1996: 471). Fathers who are highly educated, employed, and resourceful are more likely than fathers who lack these characteristics to stay in touch with their children after separation (Bradshaw et al., 1999; Cooksey \& Craig, 1998; Guzzo, 2009; Swiss \& Le Bourdais, 2009).

Social policies, such as child support payments, visitation rights, and legal custody, are additional factors that can enable or constrain paternal involvement after separation and divorce. There is consistent evidence that the amount and the regularity of child support payments are strongly correlated with a close father-child contact (Cheadle et al., 2010; Hofferth et al., 2010). Joint legal custody also seems to support a positive relationship between non-resident fathers and their children (Seltzer, 1998; Stephen et al., 1994). Obviously, however, neither joint legal custody nor child support payments are assigned at random, so that the direction of causality is difficult to establish (Nepomnyaschy, 2007; Seltzer et al., 1989). 


\section{The German Case}

In cross-national comparisons, Germany has continuously been classified as a country that favors a modernized male breadwinner model through a fine-tuned system of social policies that support men mainly as economic providers and women as part-time workers and mothers. However, since 2005, major family policy reforms have been enacted that not only facilitate the labor market integration of mothers, but also foster greater gender equity and the stronger involvement of fathers in the upbringing of their children (Adler et al., 2016; Adler \& Lenz, 2016). Although public policy attention has primarily focused on fathers' involvement in nuclear families (e.g., parental leave), some major reforms have strengthened fathers' rights after separation and divorce as well. In particular, before 1998, the rights of unmarried fathers to remain involved in the lives of their children were very limited (Peschel-Gutzeit, 2009). Since then, joint legal custody has become the "rule" for divorced parents and unmarried fathers can apply for joint legal custody during pregnancy or later.

It is important to note that in German family law, parental legal custody is the basic concept, which involves the right to have a say in the relevant areas of a child's life, such as education, care, health, and property. Joint legal custody therefore implies that major decisions concerning a child must be made jointly by the parents and those responsibilities continue after separation. Physical custody and visitation rights are separate matters. The rights and duties to contact exist irrespective of who actually holds legal custody (Dethloff, 2015).

The rules and the guidelines that lay out child support payments assume that the child will mainly reside with one parent (Dethloff, 2015). In the large majority of cases, the child lives primarily with the mother after a separation or a divorce. However, the share of separated parents in Germany who practice shared parenting is growing slowly (Kindler \& Walper, 2016). Financial child support is regulated on the national level. If a non-resident father does not meet 
his child support obligations, the resident mother can file for advance payments from the local authorities, who in turn try to collect the payment from the non-resident father.

Taken together, we expect to find that fathers who were married at childbirth are more likely to remain in contact with their children than fathers who were either cohabiting or not living with the mother at childbirth. In particular, we assume that fathers who have never resided with the mother of their children have greater difficulties in establishing and maintaining frequent fatherchild contact. In line with prior research, we furthermore assume that meeting child support obligations and having joint legal custody are positively related to father-child contact. Since married fathers automatically keep legal custody after divorce, the small group of divorced fathers who are being refused legal custody should be negatively selected and be less likely to see their children. Conversely, unmarried fathers must make an effort to apply for joint legal custody when their children are born, and may thus be positively selected with respect to their interest in getting involved in their children's lives (more father-child contact). As in previous research, we expect to find evidence for a social gradient and a negative impact of a father's repartnering and of additional children on the frequency of father-child contact after separation.

\section{METHOD \& DATA}

\section{Data and Analytical Sample}

The analyses are based on data from the German family panel pairfam ("Panel Analysis of Intimate Relationships and Family Dynamics”), a multi-disciplinary, longitudinal study of partnership and family dynamics in Germany (Brüderl et al., 2017a; Huinink et al., 2011). The annually surveyed nationwide random sample includes respondents of the birth cohorts 197173, 1981-83, and 1991-93. To allow for more in-depth comparisons of family dynamics in eastern and western Germany, a subsample (DemoDiff) was drawn in 2009/10 that oversampled eastern Germans of the cohorts 1971-73 and 1981-83 (Kreyenfeld et al., 2012). The German 
family panel is well-suited for examining how father-child contact is contingent upon the father's union history and current status, as it provides the full union histories of all respondents, including periods of living apart together relationships.

For this analysis, we pooled data from wave 2 (2009/10) to wave 8 (2015/16). We did not include data from wave 1, because the frequency of father-child contact was not yet surveyed in wave 1. Fathers can enter our sample several times, depending on how often they had participated in the survey, and can thus contributed up to seven years of data points. We studied a father's contact to his first-born child based on the information that the father provided on the frequency of contact. We controlled for whether he had further children, but our results were restricted to first-born children. Our analytical sample included men who had at least one child, but who were separated from the mother of their first-born child. We furthermore reduced the sample to men whose first-born child was age 17 or younger at the respective time of interview. The total number of separated fathers in the data was 379. We excluded fathers who (still) lived with their children, in order to focus on non-resident fathers. Also the few fathers (13 cases) who had sole legal custody were excluded. The final sample consisted of 285 fathers who contributed 947 person years to the analysis.

\section{Variables}

A note on terminology. In accordance with the literature (e.g., Amato et al., 2009; Kiernan, 2006), we use the term "non-resident father" instead of post-separation or separated father. We have chosen this term because we believe it adequately describes the life situation of the typical father after separation in Germany (Kalmijn, 2015a). In our sample, nine out of 10 fathers had a first child who mainly lives with the biological mother, and only a very small proportion of the fathers practice shared parenting with the child's mother. 
Dependent variable. In our study, the frequency of in-person contact between the non-resident father and his child was used as an expression of father-child relations after parental separation. We are well aware of the limitations of a measure that does not include forms of long-distance contact (such as communication by phone or messaging) and that does not capture the emotional closeness of the relationship (Amato \& Gilbreth, 1999). However, previous research has convincingly shown that in-person father-child contact is a necessary prerequisite for other types of contact, and for establishing an emotionally close relationship (Schier, 2016). We therefore considered the frequency of in-person contact to be a basic requirement for fatherchild relations.

In the survey, there were eight potential responses to the question "How often do you see [child’s name]?”: “1=daily,” “2=several times per week,” “3=once per week,” “4=1-3 times per month,” " $5=$ several times per year," "6=less often," " $7=$ contact broken off,” and "8=contact never established.” After careful consideration, we collapsed these responses into two groups that distinguish between " $1=$ contact at least every month (frequently)" and " $0=$ contact several times per year and less (rarely).” Therefore, our focus is on exploring the factors that affect non-resident fathers’ probability of having frequent contact versus having little or no contact with their first-born child, while accounting for the fact that it is common practice in Germany for non-resident fathers to see their children every other weekend (Schmid, 2014). Moreover, this compressed version of contact allows us to identify the characteristics of the fathers who were able to see their children regularly, and to clearly distinguish them from those who did not participate in their children's everyday lives. Before we decided to use a binary variable as an outcome, all of the multivariate analyses were also conducted using an ordinal dependent variable, which yielded very similar results. The dependent variable and all covariates were based on fathers' reports. 
Covariates. We included several covariates that reflect past and present union behavior. The family status at the time of childbirth was categorized as single/living apart together (LAT), cohabiting, or married. A time-varying covariate measured the current family status at time of interview. We distinguished between single, LAT, cohabiting, and married fathers. We also controlled for the birth of a new child. This variable is time-varying and dummy coded; it equals one if the father had a child with a current partner. We also included a variable that indicates whether the father has further children from past partnerships. These may be the full siblings of the first-born child or half-siblings from further relationships.

The legal setting of the separation had been taken into account through the inclusion of a binary variable that indicates whether the parents have joint legal custody, or whether the mother had sole custody. The respondents' custody arrangements were surveyed every second year, and we imputed the information for the interim periods. However, this information is basically timeconstant, as legal custody is usually established around childbirth (in our sample, the respondents' joint custody status changed in only 15 cases over the survey years). Furthermore, we controlled for whether the father pays child support. Child support payments are timevarying because they depend on the father's financial situation and on the child's age. The German Family Panel included a question about whether child support was paid without asking respondents to specify the payment amounts or the order of the child. Thus, we must assumed that payment of child support did not vary by the order of the non-residing children.

We also controlled for the child's current age. In order to account for non-linear effects, we distinguished between fathers with children aged 0-5, 6-11, and 12 and older. Another control variable was the duration since separation, distinguishing 0-2, 3-5, 6-8, 9-11 and 12 and more years. 
Fathers' socioeconomic resources are measured repeatedly across the waves by including their education and their employment status. The highest educational degree was measured according to the International Standard Classification of Education (ISCED) as low (no degree or lower secondary education), medium (upper secondary or post-secondary non-tertiary education), and high (tertiary education). The father's employment status consisted of three categories: employed (full-time or part-time), unemployed, and in education/other.

The fathers were further distinguished according to the place of residence at the time of the survey. Eastern Germany includes the region of the former German Democratic Republic plus West Berlin, and western Germany includes the states that composed the former Federal Republic of Germany, excluding West Berlin. (The STATA-code that generated the sample is available on the homepage of the family panel http://www.pairfam.de/en/).

\section{Analytic Strategy}

We first present our descriptive findings on the composition of non-resident fathers in Germany and on the frequency of father-child contact. The descriptive information is displayed as unweighted and weighted estimates. Here, we use a combination of a design and a poststratification weight that particularly accounts for the oversampling of eastern Germany in the sample (Brüderl et al., 2017b). Finally, the determinants of father-child contact are examined in a multivariate framework.

The frequency of father-child contact was repeatedly measured as a binary variable across the panel waves. Since we had repeated observations on each individual for each wave of the survey, in a standard logistic regression, measures on the same individual are likely to be correlated, which yields biased coefficient estimates. We used population average logistic models (PA logistic models) with robust standard errors to allow for this kind of autocorrelation. These models are particularly suitable for panel data when the interest is in the 
effect of time-constant covariates on an outcome, which is the case in our study that focuses on joint legal custody (see Szmaragd et al., 2013 for a discussion). The PA models were fitted using generalized estimating equations (GEE) (Liang \& Zeger, 1986) as an extension of standard regression estimation procedures by adjusting the estimates of the logistic model parameters and the standard errors for autocorrelation.

In a first step of our analysis, apart from the union status at childbirth, we only controlled for the basic socio-demographics (region, time since separation, age of the child). We then included the legal custody arrangement and child support payments. In the last step, we controlled for the abovementioned characteristics of the non-resident fathers. The reason for choosing a stepwise modeling procedure was to unravel whether the association between legal custody and child contact was largely driven by the particular characteristics of separated fathers with joint legal custody. We also generated models with interaction terms. The first interaction model explored the question of whether the association between joint legal custody and father-child contact differed by the father's union status at childbirth. The next interaction examined the relationship between legal custody and the time elapsed since separation.

\section{RESULTS}

\section{Descriptive Findings}

Table 1 gives an overview of the socioeconomic characteristics of our study population. In addition, the table displays the share of fathers who report having close contact with their children. We provide weighted as well as unweighted estimates. The last column of Table 1 shows the share of the non-resident fathers who have frequent contact with their first-born children: $67 \%$ in the total population reported frequent contact, but there was strong variation across subgroups. We found a strong educational gradient, with university-educated fathers being substantially more likely than less educated fathers to have frequent contact. Although 
unemployed men should have more time than employed men to see their children, they were less likely to have frequent contact: $57 \%$ of unemployed fathers, compared to $70 \%$ of employed fathers, reported having more often contact with their children. Unlike the Anglo-American studies (Tach et al., 2010), we did not find pronounced differences between men who had been living in marital and in cohabiting unions at first childbirth. However, men who were not living with the mother at childbirth were substantially less likely to report having frequent contact with their children than men who were in co-residential unions. The duration since separation, the age of the child, and the birth of a new child all had a negative impact on father-child contact. There was no notable difference in contact frequency between fathers with only one nonresiding child and fathers who had more than one child living outside their household. While having a new relationship did not seem to impact the father-child relationship, getting married to a new partner did. Very pronounced differences were found depending on the legal custody arrangements: $81 \%$ of the men who had joint legal custody had frequent contact with their children, compared to only $46 \%$ of the men whose ex-partner had sole custody. We also found smaller but still distinct differences depending on whether the father paid child support: $71 \%$ of the men who paid child support reported frequent contact, compared to $57 \%$ of the men who did not.

Table 1: Sample statistics and share of fathers with frequent contact

\begin{tabular}{lccc}
\hline & $\begin{array}{c}\text { Column \% } \\
\text { (unweighted) }\end{array}$ & $\begin{array}{c}\text { Column \% } \\
\text { (weighted) }\end{array}$ & $\begin{array}{c}\text { \% fathers with frequent contact } \\
\text { (weighted) }\end{array}$ \\
\hline $\begin{array}{l}\text { Region of Germany } \\
\text { Western Germany }\end{array}$ & 53 & 82 & 68 \\
$\quad \begin{array}{l}\text { Eastern Germany } \\
\text { Family status at first birth }\end{array}$ & 47 & 18 & 62 \\
Married & 29 & 30 & 76 \\
Cohabiting & 41 & 39 & 72 \\
LAT/Single & 30 & 31 & 53 \\
Duration since separation & & & \\
0-2 years & 24 & 25 & 89 \\
3-5 years & 22 & 22 & 71 \\
6-8 years & 19 & 18 & 54 \\
9-11 years & 16 & 16 &
\end{tabular}


$12+$ years

Age of first child

Age 0-5

Age 6-11

Age 12-17

Custody arrangement

Joint custody

Mother sole custody

Missing

Payment of child support

Yes

No

Education

Low

Medium

High

Employment status

Employed

Unemployed

In education/other

Current family status

Single

LAT

Cohabiting

Married

Others/missing

New child

Yes

No

Multiple separated living

children

Yes

No

Person-years (subjects)
19

36

76

76

54

81

46

70

71

57

$30 \quad 26$

$12 \quad 12$

62

60

79

$24 \quad 36$

70

57

57

$9 \quad 10$

68

71

72

55

80

2 1

$24 \quad 22$

61

69

78

70

37

33

66

Source: German Family Panel 2009/10-2015/16.

\section{Multivariate Results - Determinants of Father-Child Contact}

Table 2 presents the results from the PA logistic regression analysis with frequent contact as the dependent variable. Model 1 controlled for region of Germany, union status at first birth, time since separation, and age of the child. In Model 2, we added custody arrangement and 
child support payments. The socio-demographic characteristics of separated fathers were controlled for in a last step (Model 3).

Duration since separation and the age of child. In line with previous research (Stephen et al., 1994; Stephens, 1996), we found that father-child contact declined as the time elapsed since the separation increased. The age of the child did not appear to be related to the frequency of fatherchild contact. It should be noted that the time elapsed and the age of child were strongly correlated. The bivariate analyses showed a negative correlation between the age of the child and the frequency of contact, but this seemed to be largely driven by the effect of the time since the separation, which increases in tandem with the aging of the child.

Partnership status at the first birth. In line with the bivariate analysis, we found that the men who were married when their first child was born were the most likely to stay in contact with their children after divorce. The odds of frequent contact increased by $47 \%$ percent if we compared the men who were not living with the mother with the men who were married when the child was born. Living in a cohabiting union at childbirth also increased contact frequency but to a lesser extent.

Legal custody and child support. Model 2 included legal custody and child support. Unlike prior studies for Anglo-American countries (Cheadle et al., 2010; Hofferth et al., 2010), we did not find that child support is correlated with frequent father-child contact. This finding may be attributable to the legal framework in Germany, which makes it more difficult for fathers to evade child support payments. Thus, our study may be less affected than studies conducted in other countries by the self-selection of involved fathers into child support payments.

The custody arrangement was, however, shown to be strongly associated with frequent contact. If the mother has sole legal custody, the odds of frequent contact declined by about $58 \%$. After the inclusion of legal custody and child support, most of the previous coefficients remain stable. 
An exception is the union status at childbirth. The fading of its impact can be attributed to the strong correlation between marriage and joint legal custody.

Father's socioeconomic background. In line with the results of the descriptive analysis, we found that highly educated fathers were more likely than fathers with less education, and that unemployed fathers were less likely than employed fathers to have regular contact with their children. Unlike in the bivariate analysis, we no longer found that eastern Germans were less prone to have frequent contact with their non-resident children.

Partnership and fertility behavior since separation. While the fathers who were married when their first child was born were more likely to keep in touch, their chances of remaining in frequent contact lowered significantly if they remarried. Having a new relationship and a new cohabiting partner lowered contact frequency, but to a lesser extent than a marriage. Unlike in the bivariate analysis, we did not find that the birth of a new child affected father-child contact. However, as current marital status and the birth of a new child were closely correlated, it was difficult to isolate the effects, given the relatively small sample size. A father who had more than one non-residing child from a prior union did not display more or less contact with his first-born child than a father with only one child from whom he lived separately.

Table 2: Results from population average logit models, dependent variable: father-child contact ( 1 =frequently, $0=$ rarely)

\begin{tabular}{|c|c|c|c|c|c|c|c|c|c|c|c|}
\hline & \multicolumn{4}{|c|}{ Model 1} & \multicolumn{4}{|c|}{ Model 2} & \multicolumn{3}{|c|}{ Model 3} \\
\hline & $\mathrm{b}$ & $\exp (b)$ & s.e. & & $\mathrm{b}$ & $\exp (b)$ & s.e. & & $\mathrm{b}$ & $\exp (b)$ & s.e. \\
\hline $\begin{array}{l}\text { Western Germany } \\
\text { (ref.: Eastern } \\
\text { Germany) } \\
\text { Family status at } \\
\text { first birth } \\
\text { (ref: LAT/Single) }\end{array}$ & 0.11 & 1.12 & 0.23 & & 0.11 & 1.12 & 0.23 & & 0.09 & 1.09 & 0.23 \\
\hline Married & 0.93 & 2.55 & 0.32 & $* * *$ & 0.60 & 1.83 & 0.31 & $*$ & 0.38 & 1.47 & 0.33 \\
\hline $\begin{array}{l}\text { Cohabiting } \\
\text { Duration since } \\
\text { separation } \\
\text { (ref: } 0 \text { - } 2 \text { years) }\end{array}$ & 0.48 & 1.62 & 0.28 & $*$ & 0.35 & 1.43 & 0.28 & & 0.26 & 1.30 & 0.29 \\
\hline
\end{tabular}




$\begin{array}{lllllllllllll}\text { 3-5 years } & -0.52 & 0.59 & 0.21 & * * & -0.32 & 0.72 & 0.23 & & -0.29 & 0.74 & 0.22 & \\ \text { 6-8 years } & -0.91 & 0.40 & 0.29 & * * * & -0.66 & 0.52 & 0.31 & * * & -0.61 & 0.54 & 0.29 & * * \\ \text { 9-11years } & -1.13 & 0.32 & 0.28 & * * * & -0.95 & 0.39 & 0.29 & * * * & -0.93 & 0.39 & 0.29 & * * * \\ \text { 12+ years } & -1.66 & 0.19 & 0.34 & * * * & -1.49 & 0.22 & 0.36 & * * * & -1.54 & 0.21 & 0.36 & * * *\end{array}$

Age of first child (ref: 0-6)

$\begin{array}{llllllllll}\text { Age 6-11 } & -0.17 & 0.85 & 0.22 & -0.16 & 0.86 & 0.24 & -0.15 & 0.86 & 0.25 \\ \text { Age 12-17 } & -0.15 & 0.86 & 0.26 & -0.17 & 0.85 & 0.28 & -0.15 & 0.86 & 0.31\end{array}$

Custody arrangement (ref: joint) Mother sole $-0.75$ $\begin{array}{llll}0.47 & 0.24 & * * * & -0.88\end{array}$ custody Child support (ref: yes)

No

Education (ref: low)

Medium High Employment status (ref: employed)

Unemployed In education / other $\begin{array}{llllll}-0.19 & 0.82 & 0.18 & -0.13 & 0.88 & 0.19\end{array}$ Current family status (ref: Single)

LAT Cohabiting Married New child (ref: yes)

No

Further separate living children (ref: yes)

\begin{tabular}{|c|c|c|c|c|c|c|c|c|c|c|c|c|}
\hline No & & & & & & & & & -0.18 & 0.84 & 0.26 & \\
\hline Constant & 1.05 & 2.88 & 0.30 & $* * *$ & 1.41 & 4.09 & 0.39 & $* * *$ & 1.73 & 5.66 & 0.51 & $* * *$ \\
\hline Wald $X^{2}$ & 51.32 & & & & 66.19 & & & & 93.35 & & & \\
\hline Person-years & 947 & & & & 947 & & & & 947 & & & \\
\hline
\end{tabular}

Note: Controls are missing information on control variables (omitted from the table). Source: German Family Panel 2009/10-2015/16. * $p<0.05$;** $p<0.01$; *** $p<0.001$.

\section{Results from Models with Interaction Terms}

Figure 1 reports the average predicted probabilities from an interaction model of legal custody and family status at first birth. For all groups, we found that legal custody is strongly associated 
with father-child contact. However, the strength of the effect was largest for the men who were either married or not living with the mother of their child at childbirth. This result can probably be explained by selection. As divorced men have been receiving joint custody by default since 1998, those who were not granted joint legal custody are presumably negatively selected. Since unmarried men must make an extra effort to apply for joint legal custody at childbirth, this group may be positively selected. The effect of joint legal custody is strongest for the men who were not living with a partner at childbirth. Also this effect may be attributed to selection. However, it may also be the case that there is a causal effect as we have controlled for many of the factors that select men into joint legal custody. A man who has never lived with the mother of his first-born child may face high barriers to getting involved in his child's life, and joint legal custody may represent an institutional arrangement that is conducive to regular fatherchild contact. The figure also shows that fathers who had joint custody report approximately the same level of contact frequency regardless of union status at first birth.

Figure 2 displays the interaction effects of legal custody and time since separation. Due to the small number of cases, we included time since separation as a continuous covariate in the interaction model (a model with a categorical variable generates the same, but more "noisy" results). At the time of separation, there were some differences between fathers with and without joint legal custody, and these differences increased over time. Ten years after the separation, $71 \%$ of the fathers who held joint custody still saw their children regularly, whereas only $38 \%$ of the fathers whose ex-partner had sole legal custody were in regular contact with their children. This interaction model seems to suggest that the fathers who had joint legal custody were better able to maintain father-child contact over time. In other words, men without joint legal custody were considerably more likely to lose contact with their children.

Figure 1: Results from the population average logit model, predicted probabilities by legal custody and family status at first birth with 95\% confidence intervals, dependent variable: father-child contact $(1=$ frequently, $0=$ rarely) $(N=285)$ 


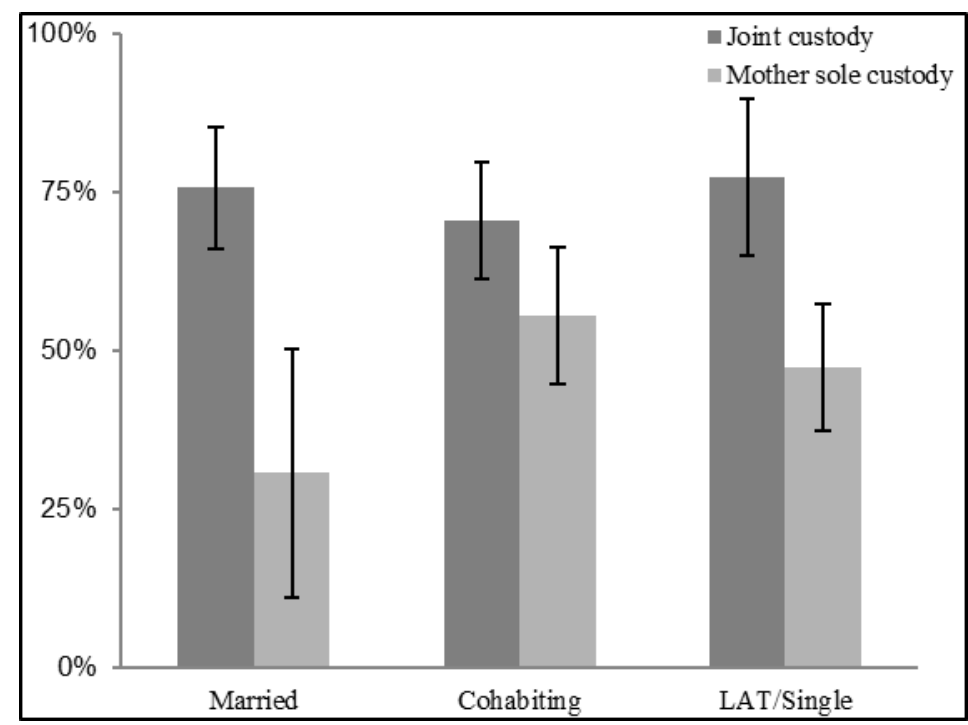

Note: Controls are the same as the variables listed in Model 3 (see Table 2).

Source: German Family Panel 2009/10-2015/16.

Figure 2: Results from the population average logit model, predicted probabilities by legal custody and time since separation with 95\% confidence intervals, dependent variable: fatherchild contact $(1=$ frequently, $0=$ rarely) $(N=285)$

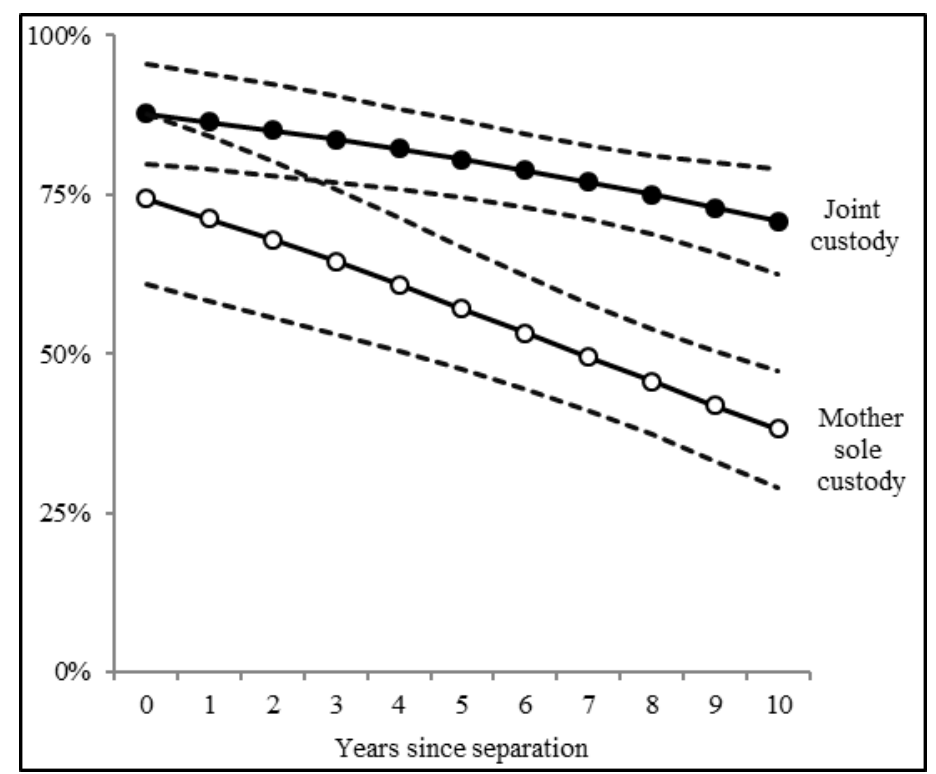

Note: The controls are the same as the variables listed in Model 3 (see Table 2).

Source: German Family Panel 2009/10-2015/16.

\section{CONCLUSION}

In this study, we examined the determinants of father-child contact in Germany, with a special emphasis on the role of legal child support. The investigation supported the findings of the 
existing literature in a number of ways. Most importantly, we corroborated the results of earlier studies that found a strong social gradient in men's post-separation behavior. We found that unemployed fathers were less likely to stay in touch with their children than employed fathers, and that university education had a positive effect on father-child contact. Prior research for Germany had shown that university education was strongly correlated with fathers' involvement in nuclear families. For example, highly educated fathers were more prone to take parental leave and to spend time with their children than less educated fathers (Geisler \& Kreyenfeld, 2018). In our study, we showed that this elevated level of involvement of fathers with tertiary education extended to post-separation behavior. While this evidence suggests that there was a social gradient in fathers' behavior, it is important to underscore that we found no differences between fathers with vocational training and fathers without secondary education. While the least educated fathers did not behave very differently from the overall population, the progressive post-separation behavior of the university-educated fathers caused this group to stand out.

A father's partnership history and his current partnership status were found to be important predictors of his contact with his children. In line with previous research (Kiernan, 2006; Skevic, 2006), we found that a father who was not living with the mother when his child was born was less likely to stay in touch with the child after separation. We also found some, albeit insignificant, differences between fathers who were in a marital or a cohabiting union at the time of the first birth. Moreover, a father's present partnership and family dynamics influenced the frequency of his contact with his children from previous unions. We found that being in a new marriage reduced the frequency of a father's contact with his non-residing child. It therefore appears that men tend to shift their investments to the family members with whom they share a household at the expense of the children with whom they no longer live (Furstenberg \& Cherlin, 1991; Tach et al., 2014). 
Also in line with the results of prior research, especially for the US, we found that fathers who made child support payments had more frequent contact with their children than fathers who did not (Juby et al., 2007; Stewart, 1999). However, this bivariate correlation vanished after we controlled for the socio-demographic characteristics of the fathers. Fathers who were less resourceful struggled in general with maintaining frequent contact with their children after separation or divorce. Whether or not they paid child support did not seem to have an independent effect on father-child contact, though.

The most social policy relevant result was a strong correlation between legal custody and fatherchild contact that was stable to the control of major socioeconomic confounders. This positive association held regardless of the father's marital status at childbirth: fathers with joint legal custody had a similarly high level of father-child contact across all union states at childbirth. In fact, frequency of contact was roughly the same for married fathers and for fathers who never lived with their first-born child, if they both had joint legal custody. In addition, joint legal custody seemed to counterbalance some of the adverse effects that the passage of time has on father-child relationships after parental separation. We found that fathers who had joint legal custody were more likely to continue to stay involved in the lives of their children as time elapsed, while other fathers tended to experience a strong decline in father-child contact over time. Having the legally approved right to take part in the decision-making on their children's life may enhance non-resident fathers’ paternal identity, even when they never physically lived with their children. Joint legal custody may provide an institutional arrangement for separated parents to exercise their responsibility for the well-being of their children and thus be conducive to regular father-child contact. Our findings lend support to the hope of policy-makers that the "status of legal custodian encourages nonresident parents to take a more active role in childrearing” (Seltzer, 1998: 135). 
There are some caveats that limit the interpretation and the generalizability of our results. Most importantly, causality has been difficult to establish in this investigation, as the causality might run both ways: having legal custody might encourage fathers to remain involved with their children, but involved fathers may self-select into having joint legal custody. We control for important socio-demographic confounders, such as education and employment. Furthermore, we exploit the fact that child custody is usually established at childbirth, and therefore tends to be fixed over time.

There are also a few limitations that pertain to the German Family Panel. The sample includes respondents of relatively young birth cohorts. Even the oldest participants were, on average, only 45 years old at the last interview. Thus, the results of the analysis may not be generalizable to individuals who were older at the birth of their first child, and thus experienced separation later in the life course. Another shortcoming of our investigation is that we examined the topic from the male perspective only. A dyadic approach that factored in the view of the mother and the child would certainly generate different results (Kitterød \& Lyngstad, 2014). This study also had to leave further questions unanswered. They concern the impact of the paternal involvement before separation and of the quality of the interparental relationship on father-child contact after separation. This information is available in the German Family Panel, but could not be exploited yet due to the still relatively short panel time. With the passage of time, the potential to thoroughly exploit fathers' life course using data from the German Family Panel will grow.

\section{REFERENCES}

Adler, M. A., \& Lenz, K. (2016). Conclusion. Comparative father involvement: The dynamics of gender culture, policy and practice. In M. A. Adler \& K. Lenz (Eds.), Father involvement in the early years: An international comparison of policy and practice (pp. 231-252). Bristol: Policy Press. 
Adler, M. A., Lenz, K., \& Stöbel-Richter, Y. (2016). Germany. In M. A. Adler \& K. Lenz (Eds.), Father involvement in the early years: An international comparison of policy and practice (pp. 61-96). Bristol: Policy Press.

Ahrons, C. R., \& Tanner, J. L. (2003). Adult children and their fathers: Relationship changes 20 years after parental divorce. Family Relations, 52(4), 340-351. doi: jstor.org/stable/3700315

Amato, P. R., \& Gilbreth, J. G. (1999). Nonresident fathers and children's well-being: A metaanalysis. Journal of Marriage and Family, 61(3), 557-573. doi:10.2307/353560

Amato, P. R., Meyers, C. E., \& Emery, R. E. (2009). Changes in nonresident father-child contact from 1976 to 2002. Family Relations, 58(1), 41-53. doi:10.1111/j.17413729.2008.00533.x

Balomatis, A. (2016). Das Wechselmodell in Europa [Shared parenting in Europe]. Neue Zeitschrift für Familienrecht, 3(18), 833-936.

Bradshaw, J., Skinner, C., Stimson, C., \& Williams, J. (1999). Absent fathers? New York/London: Routledge.

Brüderl, J., Hank, K., Huinink, J., Nauck, B., Neyer, F. J., Walper, S., . . . Wilhelm, B. (2017a). The German Family Panel (pairfam). GESIS Data Archive, Cologne. ZA5678 Data file Version 8.0.0, doi:10.4232/pairfam.5678.8.0.0.

Brüderl, J., Garrett, M., Hajek, K., Herzig, M., Huyer-May, B., Lenke, R., Müller, B., Schütze, P., Schumann, N. (2017b). pairfam data manual: Release 8.0. Retrieved from: http://www.pairfam.de/fileadmin/user_upload/redakteur/publis/Dokumentation/Manua ls/Data_Manual_pairfam_8.0.pdf

Cheadle, J. E., Amato, P. R., \& King, V. (2010). Patterns of nonresident father contact. Demography, 47(1), 205-225. doi:10.1353/dem.0.0084

Cooksey, E. C., \& Craig, P. H. (1998). Parenting from a distance: The effects of paternal characteristics on contact between nonresidential fathers and their children. Demography, 35(2), 187-200. doi:10.2307/3004051

Dethloff, N. (2015). From separation to stepfamily. A legal perspective. In U. Zartler, V. Heintz-Martin, \& O. Arránz Becker (Eds.), Family dynamics after separation: A life course perspective on post-divorce families (Sonderheft 10 der Zeitschrift für Familienforschung, pp. 205-218). Opladen, Berlin \& Toronto: Barbara Budrich.

Furstenberg, F. F. Jr., \& Cherlin, A. J. (1991). Divided families: What happens to children when parents part. Cambridge, MA: Harvard University Press.

Geisler, E., \& Kreyenfeld, M. (2018). Policy reform and fathers' use of parental leave in Germany: The role of education and workplace characteristics. Journal of European Social Policy (forthcoming). 
Guzzo, K. B. (2009). Men's visitation with nonresidential children: Do characteristics of coresidential and nonresidential children matter? Journal of Family Issues, 30(7), 921944. doi:10.1177/0192513X08327860

Haux, T., Platt, L., \& Rosenberg, R. (2015). Parenting and post-separation contact: What are the links? London: London School of Economics. CASEpaper/189. Retrieved from: http://sticerd.Ise.ac.uk/case/_new/publications/abstract.asp?index $=4650$

Hofferth, S. L., Forry, N. D., \& Peters, H. E. (2010). Child support, father-child contact, and preteens' involvement with nonresidential fathers: Racial/ethnic differences. Journal of Family and Economic Issues, 31(1), 14-32. doi:10.1007/s10834-009-9172-9

Huinink, J., Brüderl, J., Nauck, B., Walper, S., Castiglioni, L., \& Feldhaus, M. (2011). Panel analysis of intimate relationships and family dynamics (pairfam): Conceptual framework and design. Zeitschrift für Familienforschung, 23(1), 77-101.

Ihinger-Tallman, M., Pasley, K., \& Buehler, C. (1993). Developing a middle-range theory of father involvement postdivorce. Journal of Family Issues, 14(4), 550-571. doi: $10.1177 / 019251393014004005$

Juby, H., Billette, J.-M., Laplante, B., \& Le Bourdais, C. (2007). Nonresident fathers and children: Parents' new unions and frequency of contact. Journal of Family Issues, 28(9), 1220-1245. doi:10.1177/0192513X07302103

Kalmijn, M. (2015a). Father-child relations after divorce in four European countries: Patterns and determinants. Comparative Population Studies - Zeitschrift für Bevölkerungsforschung, 40(3), 251-276. doi: 10.12765/CPoS-2015-10en

Kalmijn, M. (2015b). Relationships between fathers and adult children: The cumulative effects of divorce and repartnering. Journal of Family Issues, 36(6), 737-759. doi: $10.1177 / 0192513 X 13495398$

Kaufman, G. (2013). Superdads: How fathers balance work and family in the 21st century. New York: NYU Press.

Kiernan, K. (2006). Non-residential fatherhood and child involvement: Evidence from the millennium cohort study. Journal of Social Policy, 35(4), 651-669. doi:10.1017/S0047279406000122

Kindler, H. \& Walper, S. (2016). Das Wechselmodell im Kontext elterlicher Konflikte [Shared parenting in the context of parental conflict]. Neue Zeitschrift für Familienrecht, 3(18), 820-824.

Kitterød, R. H., \& Lyngstad, J. (2014). She said, he said: Comparing mothers' and fathers' reports on the non-resident father's contact with his children. Demographic Research, 30(31), 899-910. doi:10.4054/DemRes.2014.30.31

Kreyenfeld, M., Huinink, J., Trappe, H., \& Walke, R. (2012). DemoDiff: A dataset for the study of family change in eastern (and western) Germany. Schmollers Jahrbuch, 132(4), 653660. doi:10.3790/schm.132.4.653 
Liang, K.-Y., \& Zeger, S. L. (1986). Longitudinal data analysis using generalized linear models. Biometrika, 73(1), 13-22. doi:10.1093/biomet/73.1.13

Manning, W. D., \& Smock, P. J. (1999). New families and nonresident father-child visitation. Social Forces, 78(1), 87-116. doi:10.1093/sf/78.1.87

Nepomnyaschy, L. (2007). Child support and father-child contact: Testing reciprocal pathways. Demography, 44(1), 93-112. doi:10.1353/dem.2007.0008

Peschel-Gutzeit, L. M. (2009). Entwicklung der Rechtsstellung des Vaters in den letzten 100 Jahren [The legal position of the father over the last 100 years]. In K. Jurczyk \& A. Lange (Eds.), Vaterwerden und Vatersein heute: Neue Wege - neue Chancen! (pp. 4759). Gütersloh: Bertelsmann Stiftung.

Régnier-Loilier, A. (2015). When fathers lose touch with their children after separation. In A. Régnier-Loilier (Ed.), The contemporary family in France: Partnership trajectories and domestic organization (pp. 139-157). Cham: Springer International Publishing.

Schier, M. (2016). Everyday practices of living in multiple places and mobilities: Transnational, transregional, and intra-communal multi-local families. In M. Kilkey \& E. PalengaMöllenbeck (Eds.), Family life in an age of migration and mobility: Global perspectives through the life course (pp. 43-69). Basingstoke, UK: Palgrave Macmillan.

Schmid, J. (2014). Umgang jedes zweite Wochenende und einmal wöchentlich nachmittags [Visitation every other weekend and once a week in the afternoon]. Neue Zeitschrift für Familienrecht, 1(9), 429.

Seltzer, J. A., Schaeffer, N. C., \& Charng, H.-W. (1989). Family ties after divorce: The relationship between visiting and paying child support. Journal of Marriage and Family, 51(4), 1013-1031. doi:10.2307/353213

Seltzer, J. A. (1991). Relationships between fathers and children who live apart: The father's role after separation. Journal of Marriage and Family, 53(1), 79-101. doi: $10.2307 / 353135$

Seltzer, J. A. (1998). Father by law: Effects of joint legal custody on nonresident fathers' involvement with children. Demography, 35(2), 135-146. doi:10.2307/3004047

Skevik, A. (2006). 'Absent fathers' or 'reorganized families'? Variations in father-child contact after parental break-up in Norway. The Sociological Review, 54(1), 114-132. doi:10.1111/j.1467-954X.2006.00604.x

Stephen, E. H., Freedman, V. A., \& Hess, J. (1994). Near and far: Contact of children with their non-residential fathers. Journal of Divorce and Remarriage, 20(3-4), 171-191. doi:10.1300/J087v20n03_11

Stephens, L. S. (1996). Will Johnny see daddy this week? An empirical test of three theoretical perspectives of postdivorce contact. Journal of Family Issues, 17(4), 466-494. doi:10.1177/019251396017004003 
Stewart, S. D. (1999). Nonresident mothers' and fathers' social contact with children. Journal of Marriage and Family, 61(4), 894-907. doi:10.2307/354011

Stewart, S. D. (2010). Children with nonresident parents: Living arrangements, visitation, and child support. Journal of Marriage and Family, 72(5), 1078-1091. doi:10.1111/j.17413737.2010.00751.x

Swiss, L., \& Le Bourdais, C. (2009). Father-child contact after separation: The influence of living arrangements. Journal of Family Issues, 30(5), 623-652. doi: 10.1177/0192513X08331023

Szmaragd, C., Clarke, P., \& Steele, F. (2013). Subject specific and population average models for binary longitudinal data: A tutorial. Longitudinal and Life Course Studies, 4(2), 147165. doi:10.14301/llcs.v4i2.249

Tach, L., Mincy, R., \& Edin, K. (2010). Parenting as a "package deal”: Relationships, fertility, and nonresident father involvement among unmarried parents. Demography, 47(1), 181-204. doi:10.1353/dem.0.0096

Tach, L., Edin, K., Harvey, H., \& Bryan, B. (2014). The family-go-round: Family complexity and father involvement from a father's perspective. The Annals of the American Academy of Political and Social Science, 654(1), 169-184. doi: 10.1177/0002716214528655

Townsend, N. (2002). Package deal: Marriage, work, and fatherhood in men's lives. Temple University Press. 